\title{
Manpower forecasting and modelling replacement demand: an overview
}

Citation for published version (APA):

Willems, E. (1996). Manpower forecasting and modelling replacement demand: an overview.

Researchcentrum voor Onderwijs en Arbeidsmarkt, Faculteit der Economische Wetenschappen. ROA Working Papers No. 4E https://doi.org/10.26481/umarow.199604E

Document status and date:

Published: 01/01/1996

DOI:

10.26481/umarow.199604E

Document Version:

Publisher's PDF, also known as Version of record

\section{Please check the document version of this publication:}

- A submitted manuscript is the version of the article upon submission and before peer-review. There can be important differences between the submitted version and the official published version of record.

People interested in the research are advised to contact the author for the final version of the publication, or visit the DOI to the publisher's website.

- The final author version and the galley proof are versions of the publication after peer review.

- The final published version features the final layout of the paper including the volume, issue and page numbers.

Link to publication

\footnotetext{
General rights rights.

- You may freely distribute the URL identifying the publication in the public portal. please follow below link for the End User Agreement:

www.umlib.nl/taverne-license

Take down policy

If you believe that this document breaches copyright please contact us at:

repository@maastrichtuniversity.nl

providing details and we will investigate your claim.
}

Copyright and moral rights for the publications made accessible in the public portal are retained by the authors and/or other copyright owners and it is a condition of accessing publications that users recognise and abide by the legal requirements associated with these

- Users may download and print one copy of any publication from the public portal for the purpose of private study or research.

- You may not further distribute the material or use it for any profit-making activity or commercial gain

If the publication is distributed under the terms of Article $25 \mathrm{fa}$ of the Dutch Copyright Act, indicated by the "Taverne" license above, 
Manpower Forecasting and Modelling Replacement Demand:

An Overview

ROA-W-1996/4E

Ed Willems

Research Centre for Education and the Labour Market

Faculty of Economics and Business Administration

Maastricht University

Maastricht, September 1996 
ISBN 90-5321-186-1 


\section{Contents}

Abstract

1 Introduction

2 The Manpower Requirement Approach: Aims, Methodology, and Criticism 2

3 Replacement Demand in the Manpower Requirements Approach 8

4 More Recent Manpower Studies for the Western World 14

5 Conclusions 26

$\begin{array}{lr}\text { References } & 29\end{array}$

List of Generally Used Symbols 33 


\begin{abstract}
Since the 1960s, numerous models have been developed that aim to forecast future developments on the labour market or to provide useful guidelines for achieving the desired development. This paper provides an overview of these manpower forecasting models, from the viewpoint of the modelling of replacement demand, which is the demand for labour due to the outflow of workers because of retirement, disablement, migration etc. or because of job mobility. These manpower forecasting models have focused on the modelling of total employment by economic sector, occupation, and - to a lesser extent educational category. Less attention has been paid to the modelling of replacement demand and the inflow of newcomers onto the labour market, although some studies in these fields have been published recently.

I would like to express my thanks to Lex Borghans, Andries de Grip, Hans Heijke and Patrick van Eijs (ROA) for their helpful comments and to Gerry Hughes (ESRI) for providing copies of some 'hard-to-find' references.
\end{abstract}




\section{Introduction}

Since World War II there has been a growing awareness that human capital endowments are important factors for economic growth, in addition to physical capital. Schultz (1961) and Becker (1962) were two of the first economists to state that education and training are important factors in improving productivity. The central theme of their human capital theory is that individuals can improve their productivity by investing in education and training. At a macro level this means that a country's domestic product can be enlarged by raising the educational level of the labour force, as long as the benefits are greater than the costs.

The interpretation of education as a factor of production made economists and policy makers aware of the possibility of achieving economic objectives by increasing investments in education. Investments in education at specific levels and of specific types (for instance agricultural, technical or economic) can boost the output of the various sectors of industry. This means that the educational level and composition of the labour force is a determinant of economic growth, so it is important to understand the relation between the educational structure of the work force and the economic target variable, say the gross domestic product. This has led to the development of models for educational or manpower planning.

One of the first manpower planning projects was the Mediterranean Regional Project, initiated by the Organisation for Economic Co-Operation and Development (OECD) in the early 1960s (see e.g. Parnes, 1962 and OECD, 1965). This project developed the 'manpower requirements approach'. The main objective of the Mediterranean Regional Project was to outline the educational requirements for the next fiftheen years, to reach specific targets for economic growth. The Project has baan carried out in six Mediterranean countries: Greece, Italy, Portugal, Spain, Turkey and Yugoslavia. Other approaches to educational planning include social demand projections and rate-of-return analysis (see Blaug, 1967).

After the Mediterranean Regional Project, several other research projects were initiated in many developed and developing countries (see for example Ahamad and Blaug, 1973). Most of these studies focus primarily on modelling and forecasting total labour demand. Less attention has been given to forecasting the future labour supply. Even in today's practice, the supply side of the labour market is an under-explored part of manpower forecasting (see Van Eijs, 1994).

Basically there are two ways for modelling labour supply, the stock approach, which forecasts the total supply of a specific type of labour, and the flow approach, which models the various flows of labour supply. In the latter method, a distinction is made between the flows of new entrants entering the labour market and the outflow from the labour market. The influx of newcomers consists primarily of school-leavers. The outflow of labour can be due to retirement or to early withdrawal from the labour market, for example in the case of 
married women or disabled workers. This outflow from the labour market can also be classified as the replacement demand, ${ }^{1}$ which, in addition to the expansion demand due to employment growth, constitutes the demand for labour.

The purpose of this paper is to give an overview of the methods that are used to forecast replacement demand in manpower models. However, many manpower forecasting studies make no explicit distinction between on the one hand the decrease in labour supply due to the outflow of workers and on the other hand the increased supply due to the entrance of newcomers to the labour market. Therefore, we will also focus on the modelling of labour supply in general. In considering the manpower models, particular attention will be given to the manpower requirements approach, but some other, more recent, manpower forecasting models will also be covered.

The remainder of this paper is structured as follows. Section 2 discusses the manpower requirements approach and describes its aims and methodology. This section also deals with the most important criticisms of this approach. Section 3 focuses on the modelling of labour supply in the manpower requirements approach. Section 4 describes several other more recent manpower forecasting studies. This section will also focus on the ways in which future labour supply has been forecast. Section 5 will present the main conclusions.

\section{The Manpower Requirements Approach: Aims, Methodology, and Criticism}

Aims

As was said in the introduction, the Mediterranean Regional Project (MRP) was one of the first attempts to make manpower forecasts for educational planning purposes. ${ }^{2}$ The background of this project was a goal of realizing some specific economic targets and social development. Parnes (1962, p. 9) describes the central aim of the Mediterranean Regional Project as follows:

"It represents an attempt [...] to prepare an assessment of national educational needs [...] and to arrive at detailed plans, including financial estimates, for meeting these needs. The end-product is to be a set of recommendations to policy makers in the respective national governments for action programmes in the field of education."

1. The outflow of workers, and thus the replacement demand, can result from changes on both the supply side and the demand side of the labour market. For a discussion see Willems (1996).

2. For a more extended recent overview of the background and methodology of the Manpower Requirements Approach, see Van Eijs (1993). 
Parnes mentions some objectives which are related to this general goal of the MRP:

1. Estimate the required number of graduates by level of education;

2. Given point 1, estimate the required number of teachers in the several levels of the educational system;

3. Given point 1, estimate the required facilities as schools, equipment, etc;

4. Assess the existing educational programmes and make recommendations for improvements;

5. Assess the need for new or expanded educational programmes;

6. Estimate the total costs of the expansion and improvement of the educational system in the light of points 2-5;

7. Make a time-table and annual budgets.

One has to realize that these aims of the MRP are based on an educational planning concept. The emphasis of the MRP is on determining the required outputs of the various categories of education and estimating the enrolments which would be required to achieve these outputs. Thus the models used do not primarily intend to forecast the future behaviour of demand and supply on the labour market, but rather to determine the labour supply required to achieve economic targets expressed in terms of economic growth or gross domestic product (see also Tinbergen and Bos, 1965). Parnes (1962, p. 17-18) puts it this way:

"estimating future manpower requirements in the context of educational planning is not the same as forecasting future demand in the market sense."

and:

"the idea of manpower requirements [...] relates to the functional (occupational) composition of employment that will be necessary if certain social and/or economic targets are to be achieved. The concept in other words, is more a technological than an economic one."

\section{Methodology}

Parnes distinguishes the following eight steps in the manpower requirements approach:

1. List the numbers of workers by sector of industry, occupation and educational class for the base year;

2. Forecast the size of the total labour force, or in other words the total supply of manpower, in the target year;

3. Forecast the total employment by sector of industry in the target year;

4. Allocate this employment by industry among the different occupational classes; aggregate over the sectors of industry to obtain the forecast of employment by occupation;

5. Forecast the requirements by educational type by converting the forecast of the occupational structure of employment; 
6. Estimate the future labour supply by type of education;

7. Compute the required change in annual outflow from the several types of education distinguished, given the results of steps 6 and 7;

8. Compute the required enrolments in each type of education to achieve the result of step 7.

The first step in this approach is data collection, choosing the classification system and describing the structure of employment. In the second step total labour supply has to be forecast. This step gives the 'upper limit' of the extent to which total manpower requirements can be satisfied. This total labour force projection can be based on a population forecast, combined with age-specific and sex-specific labour force participation rates: ${ }^{3}$

$$
\begin{aligned}
& L_{t}^{s}=\sum r_{x, t} P_{x, t} \\
& \text { where. } \\
& L_{t}^{s} \quad=\text { total labour force at time } t \text {; } \\
& r_{x, t}=\text { participation rate of people of cohort (age category by gender) } x \text { at time } t \text {; } \\
& P_{x, t}=\text { (forecast) population of cohort } x \text { at time } t \text {. }
\end{aligned}
$$

The participation rates can be estimated by taking into account past trends, anticipated changes in the socio-economic environment such as the increasing participation of married women, liberalization of retirement benefits and shifts in the structure of employment.

The third and fourth step are often seen as the most important and most crucial in the manpower requirements approach. Parnes describes three alternatives for producing a forecast of employment by sector of industry (step 3). The most well-known method consists of combining the economic targets for the gross domestic product, broken down by major sector, and a projection of labour productivity: ${ }^{4}$

$$
\begin{array}{ll}
\begin{array}{ll}
L_{i, t}^{d}=\frac{1}{d} @ Y_{i, t} \\
\text { wheret }
\end{array} \\
\begin{array}{ll}
L_{i, t}^{d} & =\text { total labour demand in sector } i \text { at time } t ; \\
b_{i, t} & =\text { average productivity in sector } i \text { at time } t ; \\
Y_{i, t} & =\text { (targeted) level of production in sector } i \text { at time } t .
\end{array}
\end{array}
$$

The fourth step deals with the translation of the sectoral forecasts into the demand by occupational class. The general way to do this is:

3. Parnes (1962) seldom uses mathematical descriptions explicitly.

4. For further details see Parnes (1962, pp. 30-34). 
$\underset{\text { with }}{L_{j, t}^{d}}=\sum_{i} \eta_{i, j, t} @ L_{i, t}^{d}$

whtere $\frac{L_{i, j, t}^{d}}{L_{i, t}}$

$L_{j, t}^{d}=$ total labour demand in occupation $j$ at time $t$;

$\eta_{i, j, t}=$ employment share of occupation $j$ in sector $i$ at time $t$.

There are several ways of obtaining forecasts of $\eta$, depending on the availability of manpower statistics. In the first alternative, the occupational structure of employment is estimated on the basis of past trends. Another way is to make comparisons with other countries and/or other, more modern and more technically advanced, firms. The rationale behind this comparison is that the better economic position of such countries is reflected in the occupational structure in a given sector of industry. A third approach can be used for occupations for which the labour requirements are closely linked to the size and sectoral composition of employment, such as the medical and teaching occupations. In these cases the occupational requirements can be estimated by applying predetermined coefficients to the sectoral employment structure.

In the fifth step, the forecast of the occupational structure of employment has to be converted into a forecast of future educational needs. Because there is no strict one-to-one relationship between the occupations and the required educational categories, this step is not straightforward. According to Parnes, one of the most useful ways for translating occupational employment into educational needs is on the basis of the current educational structure of employment within each occupation, thus:

$L_{k, t}^{d}=\sum \eta_{j, k, t} @ L_{j, t}^{d}$

where?

$L_{k, t}^{d} \quad=$ total labour demand for educational category $k$ at time $t$

$\eta_{k, j, t}=$ employment share of educational category $k$ in occupation $o$ at time $t$.

Parnes admits, however, that this assumes that the current situation is an optimal one, which is generally not the case.

Step 6 is to forecast future labour supply, broken down by educational category. This step will be considered in detail in section 3 . Step 7 is to compute the differences between the forecasts of labour demand $\left(L^{d}\right)$ and labour supply $\left(L^{s}\right)$. This results in a required change in the outflow from the educational system for the forecasting period. Finally, the concluding step of the manpower requirements approach is to determine the required future enrolments for the various types of education.

\section{Criticism}


Almost immediately after the advent of the manpower requirements approach there was a lot of criticism, of both the methodology itself and the aim behind the manpower forecasts: educational planning. The OECD report by Hollister (1967) represents a first complete evaluation of the manpower requirements approach in general and the Mediterranean Regional Project in particular. Blaug (1967) evaluates several approaches to educational planning, including the manpower requirements approach. Other (empirical) evaluation studies are put together by Ahamad and Blaug (1973) and Youdi and Hinchcliffe (1985). The most important criticisms raised in these evaluations will be discussed below.

The first, most general and fundamental question concerning the manpower requirements approach is whether manpower requirements have any impact on the operation of the educational system. If students' participation in the various types of education is an autonomous process, on which planning and controls have little or no effect, the manpower requirements approach cannot have any very significant impact.

Hollister however argues that this criticism of the manpower requirements approach is difficult to test. No one knows what enrolments in the various types of education would have been if no manpower requirements estimates had been made. Nevertheless, Hollister describes an approach to assessing the impact of manpower requirements forecasting, beginning with the observation that educational requirements can change for three reasons. Firstly, educational requirements may have to change in line with the growth in the labour force. Secondly, shifts in the educational structure are required in response to changes in the occupational structure of labour demand. Thirdly, educational requirements may change because of changes in the kinds of education needed in given occupations.

If the growth in the labour force is the most powerful factor behind changing educational requirements, then manpower planning analyses are not useful. In this case, the demand for labour will be affected by the supply, rather than vice versa. Conversely, the second option fits perfectly with the basic thoughts of manpower planning. In this case the demand side of the labour market determines the required educational structure of employment. However Hollister concludes, based on empirical evaluations, that the third element seems to be the most important. There are however two ways of interpreting this result. The first is to see it as evidence of a 'social demand' or 'consumption demand' for education. This means that making manpower forecasts is not useful because the supply on the labour market determines the demand. However, the second interpretation of this result matches perfectly with the manpower requirements approach. In this view the demand side of the labour market - the occupational requirements - determine the educational requirements. Therefore it is not clear whether it is useful to make manpower forecasts for educational planning. Hollister (1967, p. 66) says:

"basic doubts would be raised about the manpower requirements approach as presently practised." 
A second point of criticism is to a certain extent less fundamental. It is argued that the methods of making manpower forecasts are so weak that the degree of certainty is very low. This can be seen as an important but solvable problem. The weakest element in the first generation of forecasting models is the transformation of the occupational requirements into educational needs. The manpower requirements approach does not deal adequately with substitution processes in the labour market (see also Psacharopoulos, 1991). However Freeman (1977 and 1980) and Borghans and Heijke (1993) show how these substitution processes can be implemented in a manpower requirements model.

Ahamad and Blaug (1973) mention another important criticism of educational planning methods, which has become known as the paradox in manpower planning. On the one hand there is naturally a need for long-term forecasts, because educational adjustments have a certain time lag. On the other hand, the quality of the estimates decreases as the forecasting period increases. For this reason medium-term forecasts seem to be most appropriate.

These more or less fundamental criticisms of manpower forecasting have led to changing views of the use of the estimates these forecasts produce. From a planning orientation in the 1960s, manpower forecasting has evolved in the 1980s to a focus on market transparency. In several countries the primary purpose of making manpower forecasts is now to improve the functioning of the labour market by providing information about developments and trends on the labour market for the next few years. The premise underlying this view is that the mismatch between the educational system and the labour market is caused by the fact that students have to make their educational choices without having enough insight into the consequences of their choices. Borghans (1993) shows that the match between education and the labour market can be improved by providing information without disturbing the functioning of the market. Thus forecasts can be seen as one element of the information required for educational and vocational guidance (see e.g. Heijke, 1986 and 1993). Moreover, manpower forecasts can yield valuable information for policy purposes, especially in the fields of educational and employment policy, as an aid to understanding the effects of various courses of action on the employment structure or the labour market situation in general. The manpower forecasts can then be used as guidelines for active labour market policies in the fields of training, job placement and job creation (see also Hughes, 1993 and OECD, 1994).

\section{Replacement Demand in the Manpower Requirements Approach}

Most traditional, but also more recent, manpower studies focus mainly on modelling future employment by sector of industry, occupation and qualification (see steps 3-5 of the manpower requirements approach described above). This section will describe two important ways of modelling the future supply of manpower, and in particular of estimating 
future replacement demand, in the manpower planning approaches of the 1960s. These are the methods used by Parnes (1962) and by Tinbergen and Bos (1965). Remarkably, the methods of modelling labour supply were not empirically evaluated by Hollister (1967), and Ahamad and Blaug (1973) also paid hardly any attention to the modelling of labour supply. The book edited by Youdi and Hinchcliffe (1985) highlights the modelling of labour supply more often.

As described above, Parnes was one of the first to present a complete method for forecasting future manpower requirements. Step 6 in his method is to estimate the future supply, broken down by educational category. He distinguishes three elements of the future stock of manpower, by educational category:

- the number of workers in the category concerned;

- the influx of new entrants or re-entrants to the labour market;

- losses from the labour market due to death, retirement or withdrawal for other reasons (replacement demand).

If the labour supply is being dissagregated by occupations, movement from one occupation to the other is also an element of the future stock of labour.

Parnes distinguishes the following steps in determining the future labour supply for an occupation with a one-to-one relationship with a particular educational qualification:

1. Estimate how many current members of the labour force will withdraw due to deaths or retirements and subtract this from the current number of persons in the profession;

2. Estimate the total number of new entrants to the profession during the forecasting period, based on existing training facilities and recent trends;

3. Estimate how many of these new entrants will withdraw from the labour force due to deaths and subtract this from the result in step 2;

4. Add the results of steps 1 and 3 to get an estimate of supply for that specific occupation in the forecast year.

This can be written in a mathematical way as:

$L_{j, t+1}=L_{j, t}^{s}\left(1-\lambda_{j}\right)+L_{j, t}^{s, \text { new }}\left(1-\lambda_{y, j}\right)$

where:

$L_{j, t}^{s} \quad=$ total labour supply in occupation $j$ at time $t$;

$L_{j, t}^{s, \text { new }}=$ total number of entrants to occupation $j$ during the period $(t, t+1)$;

$\lambda_{j}=$ average outflow rate due to death or retirement for occupation $j$;

$\lambda_{y, j} \quad=$ average outflow of new entrants for occupation $j$.

For occupations which do not have a clear link with education of a particular type, some additional steps are needed: 
6.

re-enter the occupation concerned;

Estimate $\mathrm{w}$ many of the graduates from the types of education which normall supply new entrants to that occupation will in fact enter other occupations, an how many people will enter the occupation without such a 'normal' qualification;

8.

Equation (3.1) then becomes:

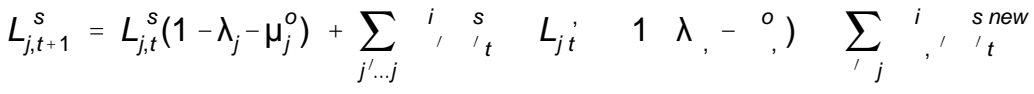

$$
\begin{aligned}
& \text {, } \quad=\quad j \\
& \mu_{a j} \quad=\quad j \\
& =\quad \text { proportion of new entrants qualified for occupation, who actuall } \\
& \text { enter another occupation; } \\
& \mu_{y j} \quad \text { aver proportion of new entrants to occupation who do not have } \\
& \text { qualification for occupation . }
\end{aligned}
$$

the teaching professions, in particular, Parnes mentions two other steps in forecastin labour ly. Firstly, to estimate how many workers will leave the labour force befor retiremen age, and secondly, to estimate how many will re-enter the profession fro outsid the labour force. However these two elements could easily be integrated in steps and 2 , respectively.

1

upational

on

labour

on

is not available, Parnes suggests

. For example, th

5. 
$2 \frac{1}{2} \%$ per year. ${ }^{6}$ Because of the generally younger age of the new entrants, $\lambda_{y}$ will be substantially smaller.

Parnes does not elaborate on step 5 of the forecasting method. He argues that it is extremely difficult to make realistic forecasts of quantities for the variables involved in steps 5 to 8 , because of the lack of data. He therefore concludes (Parnes, 1962, p. 44):

"estimates of future supplies of manpower [should] be made in terms of categories of educational qualifications rather than in terms of specific occupations".

Only steps 1-4 of the method described above are needed to estimate the labour supply by educational category. Withdrawals from the labour market, and thus the replacement demand, can be estimated as follows. If data and forecasts of the current population and labour force by five-year age intervals and by gender is available, Parnes suggests estimating the 'losses' in a particular age group $x$ in the period $(t, t+5)$ by subtracting the estimated number of men and women aged $x+5$ in the labour force in year $t+5$ from the actual number of men and women in the age cohort $x$ in year $t$.

The withdrawal rates can then be written as:

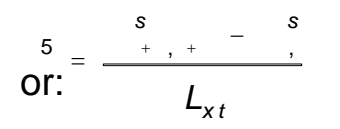

$$
\begin{aligned}
& \text { where: } \sqrt[5]{\frac{L_{x+5, t+5}^{s}-L_{x, t}^{s}}{L_{x, t}^{s}}} \\
& \lambda_{x} \stackrel{L_{x, t}}{=} \text { outflow rate due to death and retirement for workers of cohort (age category } \\
& \text { and gender) } x \text {, } \\
& L_{x, t}^{s}=\text { total labour force of cohort } x \text { at time } t \text {. }
\end{aligned}
$$

Then, using data on the current composition of the labour force by educational background, age, and sex, distribute the total losses by age and sex among the educational categories distinguished. In other words, $\lambda_{x}$ will be equal for all educational categories.

Estimating the influx of newcomers onto the labour market is, according to Parnes, somewhat more difficult. In brief, the method begins with an estimate of the number of

6. In a footnote, he warns of problems in using such a 'method' and states that the withdrawal rate can depend on the growth of the occupation in recent years. For growing professions, the withdrawal rate will be lower. On the other hand, occupations with relatively many women will have a higher replacement rate. 
students who will complete a certain type of education and will not go on to further education. Then the proportion of these who will enter the labour force has to be forecast, taking estimated deaths and participation rates into account.

\section{The Tinbergen model}

Another educational planning model was specified by Tinbergen and Bos (1965). It is one of the few early examples in which the planning model which is used is written down in a mathematical way. Future replacement demand is explicitly incorporated in the Tinbergen model. Tinbergen and Bos distinguish two educational levels: secondary and tertiary, with the assumption that completed secondary education is a prerequisite for tertiary education. They exclude primary education, because it is assumed that primary education is no bottleneck for the expansion of secondary education and for production increases, and therefore nothing has to be planned for this type of education. The basic labour supply model, formulated in time units of 6 years, ${ }^{7}$ is as follows:

$$
\begin{aligned}
& L_{2, t}^{s}=\frac{1}{\varphi_{2}} Y_{t} \\
& L_{2, t}^{s}=\left(\phi_{2}-\lambda_{2}\right) L_{2, t-6}^{s}+L_{2, t}^{s, \text { new }} \\
& L_{2, t}^{s, \text { new }}=S_{2, t-6}-S_{3, t} \\
& L_{3, t}^{s, \text { new }}=S_{3, t-6} \\
& L_{3, t}^{s}=\left(1-\lambda_{3}\right) L_{3, t-6}^{2}+L_{3, t}^{s, \text { new }} \\
& \underset{3, t}{L_{3}}=\frac{1}{b_{3}} Y_{t}+\Pi_{2} S_{2, t}+\Pi_{3} S_{3, t} \\
& L_{2, t}^{s} \quad=\text { total labour force with secondary education at time } t \text {; } \\
& L_{3, t}^{s}=\quad \quad=\text { total labour force with tertiary education at time } t ; \\
& L_{2, t}^{s, \text { new }}=\text { total number of people with secondary education entering the labour force } \\
& \text { during the period }(t-6, t) \text {; } \\
& L_{3, t}^{s, \text { new }}=\text { total number of people with tertiary education entering the labour force during } \\
& \text { the period }(t-6, t) \text {; } \\
& S_{2, t} \quad=\text { the number of students in secondary education at time } t \text {; } \\
& S_{3, t}=\text { the number of students in tertiary education at time } t \text {; } \\
& b_{2}, b_{3}=\text { average productivity of workers with secondary and tertiary education } \\
& \text { respectively; } \\
& \Pi_{2}, \Pi_{3}=\text { parameters indicating the average number of students per teacher for } \\
& \text { secondary and tertiary education respectively }
\end{aligned}
$$

7. It is assumed that both secondary and tertiary education normally involve training periods of 6 years. 
In this model, equation (3.4) shows that the labour force with a secondary education is used for production only, proportional to the volume of national production. Equations (3.5) and (3.8) state that the labour force consists of the workers who are remain from the previous period and those who have joined during the previous years. The $\lambda$ parameters represent, as before, drop-out rates from the labour force due to death or retirement. In the most simple form of the model, Tinbergen and Bos assume that $\lambda_{2}=\lambda_{3}=0.10$, which means that the replacement demand for labour with secondary and tertiary education is $10 \%$ during a 6-year period, which seems to be rather low.

Equation (3.6) states that the influx of newcomers with secondary education entering the labour force is equal to the number of students in this educational level one period earlier, less those who are now in tertiary education. The number of people entering the labour market with a tertiary education in this period is equal to the number of tertiary students one time-unit earlier (see equation (3.7)). Finally, equation (3.9) states that the workforce with a tertiary-level education works either in the production sector or as teachers in secondary or tertiary education. The $\pi$ parameters are the reciprocals of the student-teacher ratios. For example if $\pi=0.04$, the average class size is 25 students.

In this 'basic model' the modelling of replacement demand is very straightforward. Tinbergen and Bos indicate that the assumption made in equations (3.5) and (3.8) is too simple because, as a consequence of rapid development, the age composition of tertiary manpower, in particular, is biased in favour of the younger age groups. This means that a distinction has to be made between various age classes to introduce different retirement rates for each age category. Tinbergen and Bos (1965, p. 164) say:

"This introduces far more time units than were in our basic model, making it considerably more complicated. We hope such attempts will be made in the future, but have refrained from doing so ourselves".

Instead of adjusting the model in this way, they use another specification for equation (3.5):

$L_{2, t}^{s}=L_{2, t-6}^{s}-L_{2, t-T / 6}^{s, n e w}+L_{2, t}^{s, n e w}$ where:

$T=$ the productive life of an individual, in years.

This equation states that the labour force with secondary education at time $t$ is equal to those who where in the labour force at time $t-6$, minus those who entered the labour market $T / 6$ six-year periods ago, and plus those who enter from the educational system. Assuming that there is a steady growth in production and therefore also a steady growth in the labour force and the flows entering the labour force, it can be shown that equation (3.10) is equivalent to: 
$\lambda_{2}=\frac{\omega-1}{\text { where. }^{T}-1}$

$\omega=\quad$ ratio of production in year $t$ to that in year $t-6$.

\section{More Recent Manpower Forecasting Studies for the Western World}

After the first wave of manpower planning in the 1960s, mostly initiated by the OECD, manpower planning or manpower forecasting studies were made in several other countries. One of the best known examples is the Occupational Outlook Handbook of the Bureau of Labor Statistics (BLS) in the United States. Important recent manpower forecasting models in the Western world have also been developed by several institutes in Canada, by the German Institute of Employment Research (in German: 'Institut für Arbeitsmarkt- und Berufsforschung', or IAB), the Institute for Employment Research (IER) of the University of Warwick in the United Kingdom, the Irish Training and Employment Authority (FÁS) in cooperation with the Economic and Social Research Institute (ESRI), and the Dutch Research Centre for Education and the Labour Market (in Dutch: 'Researchcentrum voor Onderwijs en Arbeidsmarkt', or ROA). This section will describe the manpower forecasting activities in the United States and Canada, followed by a brief discussion of forecasting studies in Western European countries. In both cases the focus will of course be on the modelling of replacement demand.

\section{United States}

The BLS has been making long-term employment projections for the United States for almost 40 years. Biannually, the BLS presents updated forecasts of the future size and composition of the labour force, economic growth and industrial productivity, and change in employment levels by sector of industry and occupational group (see e.g. Kutscher, 1994). The main emphasis is on the occupational employment projections, which are used by occupational counsellors and policy makers, among other users (see Rosenthal, 1992).

The BLS projection model consists of six steps, which are very much like the first four steps of the manpower requirements approach presented in section 2 (see BLS, 1992). The general procedure is presented in figure 1. The first step involves making labour force projections based on trends in birth rates, death rates and net migration, disaggregated by age, gender and race. In total about 100 population categories are distinguished. Furthermore, in this first step, labour force participation rates are estimated, based on trend extrapolations for each population category.

Figure 1

BLS projection model 


$$
\text { I ul } \mathrm{t} \mathrm{n} \mathrm{n}
$$

ccu $t \mathrm{n}$ I

The second step of the foffecasting procedure is to predict the GNP and major categories of demand and income, using a macroeconomic model. Step 3 is to translate this into production by industrial secto , followed in step 4 by an input-outp/t model in which the intermediate flows of goods and services required to produce the projected GNP are estimated.

$\mathrm{L}$ urf rc

$\mathrm{Fsc}$ I $n$

$\mathrm{m} n \mathrm{t}$ ry ssum $t$ ns

In ustry- ccu $\mathrm{t} n$

$\mathrm{m} \operatorname{tr} \mathrm{x}$

Step 5 of the BLS model is to project employment levels for the influstries distinguished. These forecasts are based prmarily on the projected industry outp 4 t, taking into account the effect of expected technological labour productivity. The forecasts are obtained by extrapolating historiaalntime series.

Ch $n$ s In ustry m I ym nt

nt chn I y

The final stage of the forecastng model is to transform the estimate industry employment into projections of employmer for more than 50 occupational groups. This phase of the procedure is based on a fixed coefficient model, assuming that the employment shares of

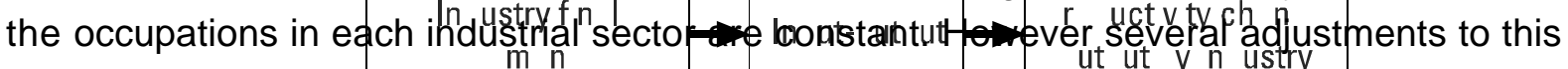
general approach are made to allow for ongoing or expected developments. Especially during this stage of the projection model, comments are requested from experts inside and outside the BLS. ${ }^{8}$

It can be seen from this overview of the BLS model that no detailed forecasts of labour supply, or of replacement demand in particular, are made. It has to be noticed that the BLS stopped making projections of future replacement demand in the early 1980s because of (Eck, 1991, p. 95):

"concerns about the quality of the data and the methods of developing data appropriate for different users."

However since the beginning of the 1990s new efforts have been made to develop a model enabling them to make "improved" estimates of replacement needs.

In this replacement demand model, presented by Eck (1991), a distinction is made between several concepts of replacement needs. The most important distinction is that between total separations and net separations. 'Total separations' refers to the flow of people leaving an occupation $^{9}$ for any reason whatsoever, while 'net separations' is an estimate of the number of openings for new entrants on the labour market to replace the workers who leave the occupation concerned. However replacement demand is not the same as separations. This is only the case if employment in the occupation is constant or increasing. If employment is decreasing, the replacement demand is less, because some individuals

8. In the literature on judgemental forecasting this is known as the 'dialectic approach' (see Sniezek, 1989).

9. The BLS replacement demand model refers only to occupations. 
who separate from the occupation will not be replaced. A distinction is also drawn between total and net replacement, analogous to the difference between total and net separations.

To estimate the total number of separations one would need detailed flow data on the labour market. However, for forecasting purposes it is the net outflow or net replacement demand which is generally used. The BLS model uses a cohort technique that is very similar to the replacement demand model developed by ROA (see later in this section). Net outflow is measured by means of the change in age groups over a 5-year period. If the size of a group decreases during this period, there is a net outflow, and if it increases there is a net inflow of new entrants. The net changes are the combined effect of transfers into and out of occupations, net migrations and labour market entry and withdrawals, including deaths. Remarkably, the BLS does not make a distinction between the net entrance and outflow patterns of men and women.

The next step in the replacement demand model is to correct for the above-mentioned difference between net separations and net replacement demand. If employment has decreased in the observation period the net separations overestimate the replacement demand. Therefore, in the case of declining employment the decrease is subtracted from the net separations, in proportion to the net outflow from each age group. This makes it possible to calculate net replacement ratios for each age group. The final step of the model is to then combine the adjusted age-specific rates with the current age structure of employment, to obtain the future net replacement needs by occupational group.

\section{Canada}

Canada is another country with a rather rich tradition of manpower forecasting. Manpower forecasts have been made since the early 1960s, with the particular aim of increasing the quality of the Canadian labour force. These models emphasize disaggregation by occupation, and seldom introduce differentiation by type of education.

\section{Figure 2}

General structure of the Canadian occupational forecasting models 
Foot (1980) presents an overview of (thme three most impiørtant Gamadiæan manpower models: COFOR: $\quad$ CEnadian Occupational Foréceatsting; HQM: $\quad$ Hiphly Qualified Manpower; TSC: $\quad$ Technicack Service Council.

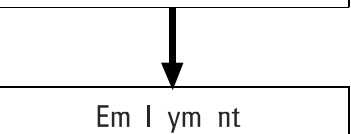

The first two mo plets referf to the public septor, whereas the lattensis a model for the private sector. The COFOR and HQM models were the basis for another, more recent Canadian manpower mooel, known as COPS: Janadian Occupational Projection System (see

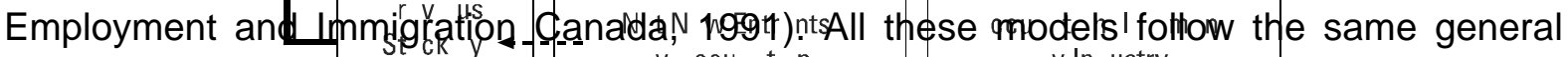
structure as presenteckin tfigure 2. The sctarting point of the demahtry side of the model is output by sector of indultry. This will be converted to the employment levels by industry and then to the occupational demand in each industry. The sum of oecupational demand

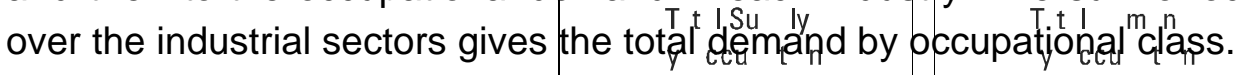

The total supply by occupation is by defihition equal to the previous stock by occupation plus the net number of new entrants in eadh orgupdrionc Thenumber of net new entrants is equal to the balance of immigration and emigration, graduation from the education system and retirement from the labour market, and occupational mobility. The differences between total supply and total demand are considered as occupational imbalances. However, as Foot argues, there may be feed-back mechanisms, for example where new suppliers entering the labour market respond to expected imbalances by occupational class when choosing their occupations.

The model as presented in figure 2 can also be put forward in equations. As before, we will focus in this paper on the supply side of the labour market. The stock of workers with a specific occupation $j$ at time $t$ can be specified as:

$L_{j, t}^{s} / L_{j, t-1}^{s}+\tilde{L}_{j, t}^{s, n e w}$ where:

$\tilde{L}_{j, t}^{s, \text { new }}=$ net number of new entrants in occupation $j$ during period $(t-1, t)$.

The net number of entrants $\tilde{L}_{j, t}^{s, n e w}$ is, as already noted, built up of four elements:

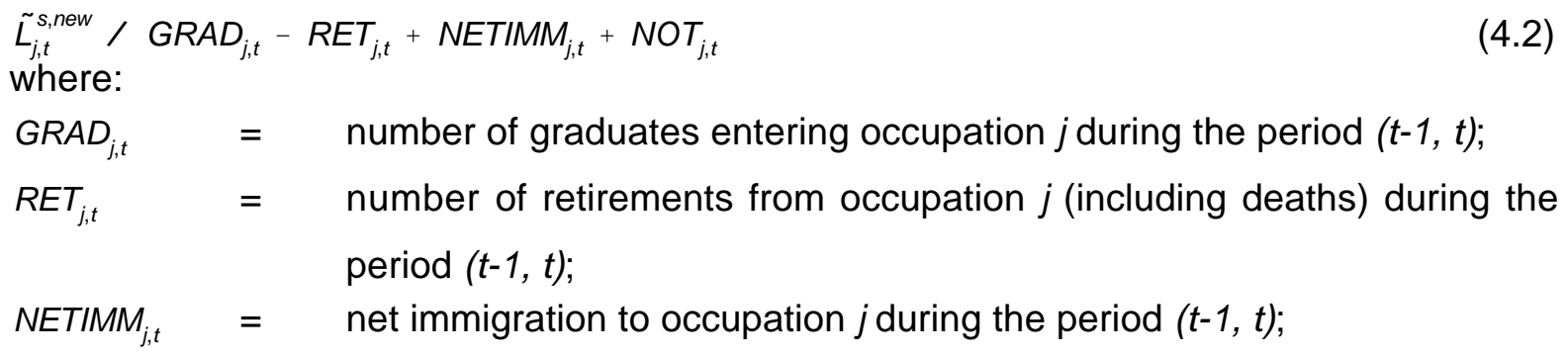


$\mathrm{NOT}_{j, t}=$ net occupational transfers into occupation $j$ during the period $(t-1, t)$.

In the COFOR model, in which almost 500 occupational categories are distinguished, a specific replacement demand projection is made. This projection distinguishes between two elements: deaths and retirements (including emigration). ${ }^{10}$ However, occupational mobility is not taken into account in this model. The number of deaths by occupation (and by province) is estimated in COFOR by applying single year-of-age and sex-specific mortality data, based on the total population, to the age and sex-specific occupational data of the Census. This means that mortality rates are independent of occupation and there is assumed to be no difference between the mortality rates of workers and non-workers. The method of estimating the number of retirements is quite similar, except that retirement rates are used instead of mortality rates. Retirement rates are obtained from the most recent Census, which means retirement is also assumed to be independent of occupation, which seems to be a very unrealistic assumption.

The HQM model distinguishes three classes of highly qualified manpower: 7 health-related occupations, 70 education-related occupations, and 68 other occupational groups, classified as technology-related. This model also includes a submodel for replacement demand. This submodel incorporates three elements of net outflow, or in Foot's terms, attrition: mortality, retirement and emigration. Occupational mobility is again not included in the model. The outflow from an occupation due to death is estimated in the same way as in the COFOR model. The overall level of emigration is not estimated but fixed at a specific number. Moreover, it is assumed that $12 \frac{1}{2} \%$ of all emigrants are from highly qualified occupations. The distribution of emigration over occupations, sex and age groups is assumed to be the same as that of the labour force.

Retirements by age and sex are estimated by taking census data on employment by occupation, age (1-year groups) and sex and comparing it with the respective total populations, implying an estimate of cohort specific 'participation rates'. This means that the difference between the number of workers of age $x$ and age $x+1$ in any occupation, for both sexes, is the combined result of mortality, retirement and emigration. Since mortality and emigration have been estimated, as described above, the number of retirements can be estimated residually. All these rates are kept constant throughout the projection period.

The TSC model distinguishes only 5 occupational categories. Furthermore, the derivation of replacement demand is simpler than in other models. In the first version of this model, specified in 1975, replacement demand was not taken into account at all. In the 1976 version the replacement demand submodel is very simple. It is assumed that $20 \%$ of the workers in the 60 to 64 year age group will retire each year, implying that everyone retires

10. This means that the flows as indicated in equation (4.2) are somewhat differently categorized. 
by the age of 65 . The mortality rate is also incorporated in the model, but the TSC model takes no account of occupational mobility.

The most recent manpower forecasting model for Canada is COPS. Like the COFOR model, COPS distinguishes almost 500 occupational categories. The model structure is also comparable with the earlier models. COPS contains a simple labour supply block with assumptions about mortality and migration. These assumptions are age and sex specific, but do not differ between occupations. The outflow due to retirement, distinguished by occupation, is estimated explicitly. Moreover, COPS has a submodel to predict future enrolments in the educational system.

\section{Western Europe}

In several Western European countries, manpower forecasts are made on a regular basis. The most important European institutes for occupational forecasting were named above: the IER, IAB, ROA and, in recent years, the FÁS/ESRI (see also Heijke, 1994 and Hughes, 1991 and 1994). ${ }^{11}$ All the institutes mentioned, except for ROA, focus on occupational demand forecasts. This means that only a few disaggregations by educational category are made. Moreover, the supply side of the labour market is hardly taken into account.

The IER has built a manpower forecasting model that is, as in the Canadian case, linked to a macroeconomic model. The model the IER has implemented is operated by Cambridge Econometrics (CE), and offers a reasonable level of industrial detail, with 49 sectors of industry distinguished. Employment by sectors is translated in several steps into demand by 22 occupational classes, 9 subject categories and 3 levels of higher education (see Wilson, 1994). The 'supply'12 component of the model is a quite simple stock-flow model (see also Hughes, 1991):

$L_{x, t+1}^{s} / L_{x, t}^{s}\left(1-\lambda_{x, t}\right)+L_{x, t}^{s, \text { new }}$

where:

$$
\begin{aligned}
& L_{x, t}^{s} \quad=\text { total labour force of age } x \text { at year } t \text {; } \\
& \lambda_{x, t}=\text { rate of 'loss' due to deaths and net migration for age } x \text { for period }(t, t+1) \text {; } \\
& L_{x, t}^{s, \text { new }}=\text { the number of newly qualified entrants into the labour force of age } x \text { during } \\
& \text { the period }(t, t+1) \text {. }
\end{aligned}
$$

These figures are then combined with projections of the labour market participation rates to obtain an estimate of how many qualified persons will be economically active. This means

11. In France occupational forecasts have been made by the BIPE (Bureau d'Information et de Previsions Economiques), among other institutions.

12. The quotation marks are Wilson's. 
that the replacement demand is not explicitly taken into account in the IER model, but is estimated implicitly by means of the (national) economic activity rates.

The German IAB has a tradition of long-term projections of manpower demand. They do not forecast future developments but, together with the Prognos institute, they give several scenarios of the future 'labour landscape' (Fuchs and Tessaring, 1994). The scenario results depend on demographic trends, trends in international economic development, the rate of technical progress and the assumed economic policy. Based on these scenario results by sector of industry, they project labour demand by occupational class. ${ }^{13}$ In contrast to the IER model, IAB uses a shift-share analysis, which distinguishes a sectoral effect, indicating the effect on the occupational structure of employment due to shifts in the sectoral employment structure, and an activity effect, which indicates the growth or decline of occupations within certain industries. The manpower demand by level of education is projected by trend extrapolation.

For a number of years the IAB has been developing and improving a macroeconometric model called SYSIFO (System for Simulation and Forecasting). This is a multi-equation simulation model consisting of six blocks, each representing specific aspects of the national economy and the international context in which it appears. These blocks are:

- economic growth;

- income and employment;

- prices and wage-price mechanism;

- trade cycles;

- money and the monetary mechanism;

- international economics.

An important concept within the SYSIFO model is the use of 'potential variables', such as the potential labour force (see also Fuchs, 1992). According to IAB it is important to define this potential labour force, because the activity rates depend on the labour market situation. The activity rate equation will usually be of the following type (see Fuchs, 1994):

$r=\alpha+\beta_{1} u+\sum_{k} \mathrm{Y}_{k} z_{k}+\epsilon$

where:

$r \quad=$ activity rate;

$u=\quad=$ labour market indicator, e.g. unemployment rate;

$z_{k} \quad=$ other explanatory variables;

$\alpha, \beta, \gamma_{k}=$ parameters to be estimated;

$\epsilon=$ error term.

13. IAB/Prognos prefers not to use the word occupation, but applies the concept of job activities (Tatigkeiten; see Fuchs and Tessaring, 1994). 
In this equation $r$ can be defined as:

where: $\frac{L^{s}}{P}=\frac{E+U}{P}$

$E \quad=$ total number of employed people;

$U \quad=$ total number of unemployed people.

This means that the total number of unemployed people is implicitly incorporated in the lefthand side of equation (4.4). This implies that it will correlate with the labour market indicator, specified in the right-hand side of that equation. This means - according to IAB that the normal definition of the labour force is not useful for labour supply forecasts. Instead, they define a potential labour force, which is the maximum labour force under conditions of high employment. The potential labour force consists of (see Fuchs, 1994):

- the normally defined labour force ('actual labour force'): employed and (registered) unemployed;

- the 'active' hidden unemployment, which means those looking for a job, but not registered at Employment Offices;

- short-term 'passive' hidden unemployment, i.e. people who 'park' in the educational system while waiting for a job;

- people who have retired early.

The first three elements together are defined by Fuchs as the 'short-term cyclical potential labour force'. The four elements together are called the 'medium-term cyclical potential labour force' or just the 'potential labour force'. If those people who would like to work if some changes in e.g. the labour laws were made, and the other non-active people, are added to the potential labour force we get the total labour force, which Fuchs equates to the total population aged 15 to 75 .

It is very difficult to measure or estimate the potential labour force or potential activity rates, but Fuchs describes several possible methods. The first consists of directly asking people, using a questionnaire, but it has proved difficult to determine in this way whether people would work in more favourable labour market situations.

A second approach is 'inflow/outflow accounting'. In this method the labour market inflow is estimated using the numbers of graduates from the educational system. The outflow - or replacement demand - could also be estimated, distinguishing between the different reasons why people leave the labour market: death, disablement, retirement, etc.. The outflow from the 'actual' labour force, for example due to early retirement schemes or the discouraged worker effect, can be explicitly excluded but it is difficult to know whether people are part of the hidden labour force, for instance those attending additional education while waiting for employment. This implies that this method can not exactly determine the potential labour force. 
The third approach is to take data from the 1960 s as a starting point, on the assumption that in these years of high employment the potential labour force was equal to the actual labour force. The current potential labour force can be estimated by trend extrapolations. One important disadvantage of such a method is that behavioural adjustments since 1970 are not taken into account. For example, after many years of discouragement one can get used to not working, which can lead to a permanently negative attitude towards employment. ${ }^{14}$

The fourth alternative for estimating the potential labour force is the one adopted by IAB. An explanatory model for the actual activity rates is first estimated, using explanatory variables such as household structure, level of education, age, gender, etc. These equations include a labour market indicator (compare equation (4.4)). The next step is to introduce a fictitious high employment level in the model by modifying the value of the labour market indicator. In this way projections of the potential activity rates are obtained.

The FÁS and ESRI, together, have been making industry and occupational forecasts for the Republic of Ireland for some years. At present they produce only a labour demand forecast, differentiated by 42 occupational categories. Little attention has been given to modelling labour supply, except that national projections - not differentiated by occupations or types of education - have been made of the total potential labour force and changes in the potential labour force. However, in this FÁS/ESRI model the labour force is not really forecast, but it is assumed that the participation rate of women between 25 and 64 will rise by one percentage point per year (see Fitz Gerald and Hughes, 1994).

In contrast to this modern Irish model, an earlier manpower forecasting model for Ireland called the 'National Manpower Forecasting Model' did include a complete forecast of supply and demand and a comparison between the two (see Corcoran and O'Kelly, 1969). The model consists of seven steps, roughly equivalent to the manpower requirement approach discussed in section 2. Step 1 involves economic forecasts of the growth of the main sectors of the economy. In the second step, these forecasts are disaggregated to obtain the demand by industrial group. In steps 3 and 4 the demand forecasts are translated into demand for occupational groups.

Step 5 is the forecast of labour supply, using a commonly-used approach which has already been mentioned. The number of survivors from the present population with a certain occupation is first estimated. Furthermore, assumptions are made with respect to occupational mobility, retirement, and withdrawals. The supply forecasts are completed with estimates of net immigration and the outflow from the educational system.

14. In economic literature this is referred to as 'habit formation'. See for example Vendrik (1993). 
Step 6 is to compare demand and supply. In this step substitution between one occupation and another is also taken into account. The sixth step produces information about what types of education should be encouraged or discouraged. Step 7 is optional, and refers to the possible regionalization of the model.

The last manpower model we want to mention is ROA's forecasting model for the Netherlands. This model differentiates between both occupational groups and types of education at detailed levels. Demand and supply are compared by type of education. Employment forecasts are made for both types of education and occupational groups. The starting point of these models is the sectoral employment forecast of the Dutch Central Planning Bureau. With the aid of two econometric models, ROA transforms these forecasts into the demand by 93 occupational groups and the demand by 49 educational types, respectively. ${ }^{15}$

The ROA model explicitly includes a determination of replacement demand, ${ }^{16}$ for the same detailed occupational and educational categories (see Willems and De Grip, 1990 and 1993). The BLS model of Eck (1991), which was described above is similar to the ROA replacement demand model. The first step in the ROA model is to derive the net outflow. Because there is no flow data available for the Netherlands, these flows are computed from stock data. Using the cohort components method, known from demographic theory, 'cohortchange rates' are estimated. These are based on the number of workers of the same birth cohort in a certain occupational class or type of education at two different times. These cohort-change rates can be considered as net inflow or outflow rates, which can be specified as follows (compare equation (3.3)):

$\tilde{\lambda}_{j, x}^{E^{n}}=\frac{E_{j, x+n, t}-E_{j, x, t-n}}{E_{j, x, t-n}}$

or:

$\tilde{\text { d. }}_{\text {.here }}^{E} \sqrt[n]{\frac{E_{j, x+n, t}-E_{j, x, t-n}}{E_{j, x, t-n}}}$

$\tilde{\lambda}_{j, x, t}^{E^{n}} \quad=$ annual net inflow or outflow rate of workers with occupation ${ }^{17} j$ of age group $x$ at time $t-n$ during the period $(t-n, t)$;

$E_{j, x, t} \quad=$ number of workers with occupation $j$ of age group $x$ at time $t$.

15. See De Grip, Borghans and Willems (1995) for further details.

16. Some earlier Dutch manpower forecasting models also explicitly distinguish the replacement demand. See, for example, the AMO-K model of Heijke, De Koning, Maas and Den Broeder (1982). Earlier versions of the ROA replacement demand model for educational categories simply assume that the future replacement demand during a seven-year period is equal to the outflow of workers aged 55 or older. See e.g. De Grip, Heijke, Dekker and Groot (1987).

17. A similar equation can be specified for the educational types. 
This model distinguishes between 10 age categories $(15-19,20-24, \ldots, 60-64)$ and, in contrast to the BLS model, also between the two sexes. This means that 20 flow coefficients are estimated for each occupation and type of education. Note that in this ROA model no distinction is made between the various causes of labour market outflow (retirement, disablement, etc.). This also implies that the replacement demand aggregated by occupational class is not equal to the replacement demand aggregated by type of education, as the former contains the outflow due to job-to-job mobility and the latter does not.

The second step of the ROA replacement demand model is to determine the future net outflow rates. In addition to the method used in the BLS model and described above, two corrections are applied to the historically observed rates. The business cycle correction offsets the outflow of workers who become unemployed due to cyclical fluctuations in employment. It is defined as the difference between the change in the total number of workers and the change in the labour force in the past period. The second correction factor, which refers to the effect of the overall participation rate (by age and gender), is equal to the difference between the growth of the labour force in the historical and the forecasting period. The future net outflow rates are then given by:

$$
\begin{aligned}
& \tilde{\lambda}_{j, x, t+n}^{E}=\tilde{\lambda}_{j, x, t}^{E}+\tilde{\lambda}_{x, t}-\lambda_{x, t}^{E}+\tilde{\lambda}_{x, t+n}-\tilde{\lambda}_{x, t} \\
& \text { where: } \\
& =\tilde{\lambda}_{j, x, t}^{E}-\tilde{\lambda}_{x, t}^{E}+\tilde{\lambda}_{x, t+n} \\
& \tilde{\lambda}_{j, x, t+n}^{E}=\text { forecast annual net inflow or outflow rate of workers with occupation } j \text { of age } \\
& \text { group a at time } t \text {, during period }(t, t+n) \text {; } \\
& \tilde{\lambda}_{x, t}=\text { annual growth rate of the total labour force of age group } a \text { at time } t-n \text { during } \\
& \text { period }(t-n, t) \text {; } \\
& \tilde{\lambda}_{x, t}^{E} \quad=\text { annual growth rate of the number of working persons of age group a at time } \\
& t-n \text { during period }(t-n, t) \text {; }
\end{aligned}
$$

The third and final step of the model is to determine future replacement demand. Firstly, the net outflow is calculated by combining the future net outflow rates, distinguished by age category and gender, with the demographic structure in the occupational class or education category concerned. For growing occupational or educational groups this net outflow is equal to the replacement demand. However, for occupations and types of education which face decreasing employment, not all vacancies due to the net outflow of workers will be filled. This implies that in such cases the replacement demand is - as in the BLS approach - equal to the number of vacancies that will be filled, i.e., the net inflow. This is by definition equal to the net outflow minus the decrease in employment.

In the ROA model, the replacement demand is added to the expansion demand to obtain total future demand. This is compared to the supply forecasts, consisting of the flow of 
schoolleavers entering the labour market during the forecast period plus the number of unemployed people at the beginning of this period. The differences between future demand and supply flows are the 'ex-ante' discrepancies on the labour market. These are translated in 'ex-post' discrepancies, taking account of possible substitution mechanisms (see Borghans and Heijke, 1993). These results are then expressed in forecasts of the prospects for newcomers entering the labour market, which are expressed using an 'indicator of the future labour market situation'. In general terms this indicator is the ratio between future supply and future demand, including substitution effects (see further De Grip, Borghans and Willems, 1995). By means of this indicator the prospects for newcomers to the labour market are characterized as good, reasonable, moderate or poor.

\section{Conclusions}

This paper has provided an overview of the most important manpower forecasting studies since the 1960s. One of the earliest and most well-known forecasting models is the manpower requirements approach which was applied in the Mediterranean Regional Project. This project, initiated by the OECD, aimed to raise the level of economic activity in Mediterranean countries by improving the educational capacity of the labour force. Therefore a system of educational planning was needed.

Apart from the Mediterranean Regional Project, several other manpower forecasting models have been developed. However, the function of these models has shifted from the pure educational planning approach to a transparency approach, in which the aim is not to give a guideline for future investments in education, but to improve the information on (future) developments on the labour market. This information will enable the labour market actors (students, firms and policy makers) to make better decisions.

This paper discussed recent manpower models for the United States, Canada and several Western European countries (see the overview in table 1). It can be concluded that most manpower forecasting models focus primarily on modelling future labour demand (employment). Less attention has been paid to modelling replacement demand. Moreover, the replacement demand models that have been used, especially in the 1960s, are very simple. Most models apply constant rates for mortality, retirement, migration, etc., generally broken down by age category and gender, although even that is not always the case. Another drawback of most replacement demand models is that occupational mobility is not included.

During the 1970s and 1980s, manpower forecasting models almost all neglected the modelling of labour supply and replacement demand. The reasons for this are not evident, although it might have been prompted by various experiences with making supply forecasts. Firstly, the aim of manpower forecasting has been largely shifted away from 
educational planning, partly because of criticisms of the first generation of manpower models. Secondly, and related to this, there has been a growing awareness that gaps between demand and supply which are forecast are difficult to interpret. The traditional models did not take into account the possibilities of substitution between different categories of skilled labour, which is of course not a valid assumption. These two developments resulted in a focus on forecasts by occupational categories rather than by educational category. Most modern forecasting activities consist of making projections on trends in the employment structure by occupational group, which requires no supply forecasts.

There is also a technical problem in predicting future labour supply, because in many countries data on the inflow and outflow of workers is not available at a detailed level. This has meant that data on the entire labour force or even the whole population would have to be used, which could only be done on the unrealistic assumption of equal retirement and outflow rates for every occupational or educational category. This may have contributed to the decision not to make flow forecasts at all. Another approach to overcome this problem is to use detailed stock data to estimate flows. This method has been adopted by both ROA and the BLS, and seems to be a promising way of making replacement demand forecasts. 
Table 1

Replacement demand in manpower models

\begin{tabular}{|c|c|c|c|c|c|c|c|}
\hline & MRP & BLS & $\begin{array}{l}\text { COFOR/HQM/ } \\
\text { TSC }\end{array}$ & IER & IAB & FÁS/ESRI & $\mathrm{ROA}$ \\
\hline country & $\begin{array}{l}6 \text { OECD- } \\
\text { countries }\end{array}$ & USA & Canada & U.K. & Germany & Ireland & Netherlands \\
\hline replacement demand included & yes & since 1991 & yes & not explicitly & not explicitly & no & yes \\
\hline \multicolumn{8}{|l|}{ specification of outflow rates } \\
\hline by age category and gender & if possible & only age & generally yes & - & - & - & yes \\
\hline by several causes of outflow & if possible & & generally yes & - & - & - & no \\
\hline by occupational or educational category $g$ & generally not & yes & no & - & - & - & yes \\
\hline job mobility included & if possible & implicitly & no & - & - & - & implicitly \\
\hline time varying & no & no & no & - & - & - & minor adjustments \\
\hline remarks & & only net flows & & & & & only net flows \\
\hline
\end{tabular}




\section{References}

Ahamad, B. and M. Blaug (eds) (1973), The Practice of Manpower Forecasting, Elsevier, Amsterdam.

Becker, G.S. (1962), 'Investment in Human Capital: A Theoretical Analysis', Journal of Political Economy, pp. 9-49.

Blaug, M. (1967), 'Approaches to Educational Planning', The Economic Journal, Vol. 76, June, pp. 262-287.

Borghans, L. (1993), Educational Choice and Labour Market Information, dissertation, Research Centre for Education and the Labour Market, Maastricht.

Borghans, L. and H. Heijke (1993), Forecasting the Educational Structure of Occupations: $A$ Manpower Requirement Approach with Substitution, ROA-RM-1993/2E, Maastricht.

Bureau of Labor Statistics (1992), Outlook 1900-2005, U.S. Department of Labor, Washington DC, Bulletin 2402.

Corcoran, J. and M.E.J. O'Kelly (1969), 'Manpower Planning', Manpower and Applied Psychology, Vol. 3, Nos. 1-2, pp. 3-10.

De Grip, A., L. Borghans and E. Willems (1995), Methodology of the ROA Information System on Occupational Groups and Types of Education, ROA-W-1995/1E, Maastricht.

De Grip, A., J.A.M. Heijke, R.J.P. Dekker and L.F.M. Groot (1987), Labour Market Prospects for Occupations and Academic Studies in 1992, ROA-W-1987/1E, Maastricht.

Eck, A. (1991), 'Improved Estimates of Future Occupational Replacement Needs', Monthly Labor Review, November, pp. 95-102.

Employment and Immigration Canada (1991), Notions and Numbers: The Canadian Occupational Projection System (COPS), Labour Market Outlook and Sectoral Analysis, Strategic Policy and Planning, Ottawa.

Fitz Gerald, J. and G. Hughes (1994), Labour Market Outlook and the Structure of Employment in Ireland in 1997, Paper presented at the European Symposium on Labour Market Developments, Scarman House, University of Warwick, May 19-20.

Foot, D. (1980), Labour Market Analysis with Canadian Macroeconometric Models: A Review, Centre for Industrial Relations, Toronto.

Freeman, R.B. (1977), 'Manpower Requirements and Substitution Analysis of Labor Skills. A Synthesis', in: R.G. Ehrenberg (ed.), Research in Labor Economics. An Annual Compilation of Research, JAI Press, Connecticut.

Freeman, R.B. (1980), 'An Empirical Analysis of the Fixed Coefficient "Manpower Requirements" Model, 1960-1970', Journal of Human Resources, Vol. 15, No. 2, pp. 176-199.

Fuchs, J. (1992), Zu- un Abgangsrechnung für die Erwerbstätigen nach Branchen. Ein Model zur Fortschreibung sektoraler Beschäftigungsstrukturen nach Alter, Geslecht und Stellung im Beruf, Beitrage zur Arbeitsmarkt- und Berufsforchung 166, IAB, Nürnberg.

Fuchs, J. (1994), Long-term Labour Force Projections for Germany. The Concept of Potential Labour Force, Paper for the ECE/Eurostat Joint Work Session on Demographic Projections, Monsdorf-les-Bains, Luxembourg, June 1-4.

Fuchs, J. and M. Tessaring (1994), Medium and Long-term Forecasting of Employment in Germany, in: H. Heijke (ed.), pp. 37-53.

Heijke, J.A.M. (1986), The Research Centre for Education and Labour Market, ROA-R-1986/1E, Maastricht.

Heijke, J.A.M. (1993), Towards a Transparent Labour Market for Training Decisions: in Europe's Human Resources in the 1990's. Report from the 1993 Cumberland Lodge Conference, prepared by TARGET with support from the European Commission, Task Force Human Resources, Education, Training and Youth, pp. 60-75. 
Heijke, H. (ed.) (1994), Forecasting the Labour Market by Occupation and Education, Kluwer Academic Publishers, Boston etc.

Heijke, J.A.M., J. de Koning, R.J.P. Maas, G. den Broeder (1982), AMO-K; Een arbeidsmarktmodel met twee categorieën arbeid, NEI, Rotterdam.

Hollister, R. (1967), A Technical Evaluation of the First Stage of the Mediterranean Regional Project, OECD, Paris.

Hughes, G. (1991), Manpower Forecasting. A Review of Methods \& Practice in Some OECD Countries, Dublin, FÁS/ESRI.

Hughes, G. (1993), Projecting the Occupational Structure of Employment in OECD Countries, OECD, Paris, Labour Market and Social Policy Occasional Papers. No. 10.

Hughes, G. (1994), An Overview of Occupational Forecasting in OECD Countries, Paper for the ECE/Eurostat Joint Work Session on Demographic Projections, Monsdorf-les-Bains, Luxembourg, June 1-4.

Kutscher, R. (1994), Projections of the U.S. Labor Force and Employment, Paper for the ECE/Eurostat Joint Work Session on Demographic Projections, Monsdorf-les-Bains, Luxembourg, June 1-4.

Organisation for Economic Co-operation and Development (1965), The Mediterranean Regional Project. An Experiment in Planning by Six Countries, OECD, Paris.

Organisation for Economic Co-operation and Development (1994), Employment Outlook, OECD, Paris.

Parnes, H.S. (1962), Forecasting Educational Needs for Economic and Social Development, OECD, Paris.

Psacharopoulos, G. (1991), 'From Manpower Planning to Labour Market Analysis', International Labour Review, Vol. 130, No. 4, pp. 459-474.

Rosenthal, N.H. (1992), 'Evaluating the 1990 Projections of Occupational Employment', Monthly Labour Review, August, pp. 32-48.

Schultz, T.W. (1961), 'Investment in Human Capital', American Economic Review, Vol. 51, pp. 1-17.

Sniezek, J.A. (1989), 'An Examination of Group Process in Judgemental Forecasting', International Journal of Forecasting, Vol. 5, No. 2, pp. 171-178.

Tinbergen, J. and H.C. Bos (1965), 'A Planning Model for the Educational Requirements of Economic Development', in: Organisation for Economic Co-operation and Development, The Residual Factor and Economic Growth, OECD, Paris.

Van Eijs, P. (1993), The Manpower Requirements Approach: Background and Methodology, ROA-RM-1993/3E, Maastricht.

Van Eijs, P. (1994), Manpower Forecasting in the Western World. The Current State of the Art, ROA-RM-1994/1E, Maastricht.

Vendrik, M. (1993), Collective Habits and Social Norms in Labour Supply. From Micromotives to Macrobehaviour, Dissertation no. 93-18, Faculty of Economics and Business Administration, University of Limburg, Maastricht.

Willems, E. (1996), Determinants of Replacement Demand on the Labour Market, ROA, Maastricht, forthcoming.

Willems, E.J.T.A. and A. de Grip (1990), Replacement Demand Forecasts by Occupation and Education, ROA-W-1990/7E, Maastricht.

Willems, E.J.T.A. and A. de Grip (1993), 'Forecasting Replacement Demand by Occupation and Education', International Journal of Forecasting, Vol. 9, No. 2, pp. 173-185.

Wilson, R. (1994), Modelling and Forecasting the Structure of Employment in the United Kingdom, in: H. Heijke (ed.), pp. 9-35.

Youdi, R.V. and K. Hinchcliffe (eds.) (1985), Forecasting Skilled Manpower Needs. The Experience of Eleven Countries, Paris, UNESCO International Institute for Educational Planning. 


\section{List of Generally Used Symbols}

b labour productivity

E number of employed people

$i$ sector of industry index

j occupation index

$k$ educational category index

$L^{d} \quad$ labour demand

$L^{s} \quad$ labour force, labour supply

$L^{s, n e w}$ number of new entrants into the labour force

$\tilde{L}^{\text {s,new }}$ net number of new entrants

$P \quad$ population

$r \quad$ labour market participation rate

$t \quad$ time index

$U \quad$ number of unemployed people

$x \quad$ cohort index (age category and gender)

$Y \quad$ level of production, gross domestic product

$\lambda \quad$ labour market outflow rate

$\tilde{\lambda}$ net labour market outflow rate

$\tilde{\lambda}^{E} \quad$ net outflow rate of workers (including net mobility) 